\title{
Alternative strategies for scaling up marine coastal biodiversity conservation in Chile
}

\author{
Stefan Gelcich ${ }^{1,2^{*}}$, Leornardo Peralta ${ }^{3}$, C Josh Donlan ${ }^{4}$, Natalio Godoy ${ }^{1,2}$, Veronica Ortiz ${ }^{1,2}$, Sebastian Tapia-Lewin ${ }^{1,2}$, \\ Camila Vargas ${ }^{1,2}$, Andres Kein $^{1,2}$, Juan Carlos Castilla ${ }^{1,2}$, Miriam Fernandez ${ }^{1}$ and Francisco Godoy ${ }^{1,2}$
}

\author{
* Correspondence: \\ sgelcich@bio.puc.cl \\ ${ }^{1}$ Centro de Conservación Marina, \\ Departamento de Ecologia, \\ Pontificia Universidad Católica de \\ Chile, Alameda 340, Santiago \\ 8331150, Chile \\ ${ }^{2}$ Center of Applied Ecology and \\ Sustainability (CAPES), Facultad de \\ Ciencias Biológicas, Pontificia \\ Universidad Católica de Chile, \\ Alameda 340, Santiago 8331150, \\ Chile \\ Full list of author information is \\ available at the end of the article
}

\begin{abstract}
The continued degradation of marine ecosystems, along with the ecosystem services they provide, suggest that new, innovative approaches are needed to scale up marine biodiversity protection and promote sustainable fishery practices. We synthesize information from Chile on the key processes involved in the development of alternative strategies for scaling up marine biodiversity conservation and discuss the complementarities with marine protected areas. Defined as "ancillary" marine conservation initiatives under the Convention of Biological Diversity, we suggest that these alternative strategies have the potential to capitalize on local stakeholders' participation and contribute to solving livelihood and governance issues while playing a significant role in scaling up marine conservation. We specifically focus on two recent ancillary initiatives being piloted in Chile. The development of business model innovations which could enable biodiversity benefits from territorial user rights fisheries policies and the creation of municipal conservation areas. We identify how these initiatives could eventually help scale up marine conservation, discuss opportunities and challenges from these pilot experiences and conclude with the need for developing policy frameworks and cross-scale governance approaches which formally acknowledge marine ancillary conservation measures as part of an integrated way to manage marine biodiversity. Exploring and supporting alternative complementary marine conservation strategies is particularly relevant in Chile and Latin America, if biodiversity conservation initiatives are to scale in coverage, contribute to livelihood improvement of local communities, replenish fisheries and play key roles in adaptation to climate change.
\end{abstract}

Keywords: Marine conservation; Territorial user rights; Navidad; Artisanal fishers; Municipalities; Marine protected area

\section{Introduction}

In 1992 the Convention on Biological Diversity set ambitious marine conservation targets, aiming to protect at least $10 \%$ of all marine ecological regions by the year 2012 (Wells et al. 2007). This target was not achieved and re-emphasised in 2010, with a new strategic plan to enhance international efforts at stopping degradation of the world's biological heritage termed the 'Aichi Targets' (CBD 2013). The target includes developing a network of well managed Marine Protected Areas (MPAs) defined by the World Conservation Union (IUCN), as any area of inter- or sub-tidal terrain with its overlying water, associated biodiversity, historical and cultural features, which has been

\section{Springer}


reserved by law or other effective means, to protect part or all of the enclosed environment (Kelleher 1999; Wells et al. 2007).

While the initial scientific focus for MPAs was on site selection (Turpie et al. 2000) and biological responses of species under protection (Micheli et al. 2004; Lester and Halpern, 2008), MPAs are now created not only to conserve seascapes and provide habitat for endangered sea-life, but also to contribute to the livelihood of local communities, to support national economies through tourism revenues, to replenish fisheries and to play key roles in adaptation to climate change, among many other functions (Watson et al. 2014). In this sense, multidisciplinary research efforts on MPAs have shifted towards defining conditions for effective management and enforcement. This has led to the recognition of the widespread occurrence of "paper-MPAs": marine protection occurs only in theory due to a lack of enforcement and management, due to the exclusive use of top-down implementation mechanisms, and lack of appropriate funding (Mora et al. 2006; Gravestock et al. 2008; Reid-Grant and Bhat 2009).

As a consequence, if marine conservation is going to effectively contribute to fulfill its multiple roles and also scale up and meet Aichi Targets, there is a pressing need to enhance the complementarities between MPAs and other management tools, by means of instruments that the Convention of Biological Diversity have termed "ancillary marine conservation initiatives" (CBD 2004). Ideally these ancillary instruments should allow participation of civil society in planning, implementing, and day-to-day management. Here, we synthesize information on two alternative strategies which could potentially serve as ancillary marine conservation instruments in Chile. We specifically explore business model innovations which could enable biodiversity benefits from territorial user rights fisheries policies (TURFs) and municipal conservation areas as ways in which Chile can scale up coastal marine conservation while securing coastal livelihoods and good governance.

\section{Review}

\section{Chilean marine coastal conservation}

In Chile, the main legal tools that exist for the implementation of MPAs take the form of Natural Sanctuaries, National Monuments, Marine Parks, Marine Reserves and Multiple use MPAs (Castilla 1996; Fernández and Castilla 2005; Castilla 2008). The goal of establishing Natural Sanctuaries, Natural Monuments and Marine Parks is to preserve natural ecosystems, while also allowing for educational and research activities. Marine Parks are non-take areas in coastal or open ocean waters where marine resources are off limits to any extractive uses. In contrast, Marine Reserves allow for the rational and sustainable exploitation of resources (Fernández and Castilla, 2005). Multiple Use MPAs have been the latest addition to the marine conservation policy instruments in Chile. Multiple use MPAs were first implemented with funding by the Global Environmental Facility, and are meant to act as an "umbrella-like" tool which considers the management of multiple ecosystem services within MPA boundaries (Gelcich et al. 2013).

Despite the existence of a suite of conservation tools, biodiversity conservation in Chile is underfunded, including MPAs (Castilla 2008; Gelcich et al. 2013; Waldron et al. 2013). Chile is one of four countries that are in bottom quartile of relative biodiversity 
conservation funding and the top quartile of threatened biodiversity (Waldron et al. 2013). The inability to direct funds to regulate and enforce MPAs has been identified as one of the main causes that lead to their failure (Mora et al. 2006; Gravestock et al. 2008). For MPAs in Chile, revenues from tourism are not sufficient to finance running costs and enforcement. For example, Lafken Mapu Lahual, one of the largest multiple use MPAs in continental Chile, could only achieve around $10 \%$ of running costs, in the most favorable conditions, under current management scenarios (Gelcich et al. 2013).

Despite funding constraints, the number of MPAs has increased significantly in the past years. There are currently 22 coastal areas which are protected in continental Chile (Ministerio de Medio Ambiente, 2014; Figure 1). These account for approximately $900 \mathrm{~km}^{2}$, which considers both coastal terrestrial portions as well as marine areas within the protected sites. Yet, there are still important gaps in surface and habitat representation of protected marine ecosystems (Tognelli et al. 2009). In response, the Environmental Ministry is considering the establishment of new multiple use MPAs as a way to scale up marine conservation efforts in coastal zones. In addition to the funding constraints, this strategy will be strife with additional challenges. For example, even at the current level of MPA representation, artisanal fishers have the perception that MPAs could cause conflicts due to issues around resource access (Gelcich et al. 2009a).

Budget constraints and low stakeholder buy-in represent two premier challenges for marine biodiversity protection in Chile and elsewhere. As mentioned, we discuss two approaches, namely, the establishment of business model innovations to incentivize biodiversity benefits form TURFs and the establishment of Municipal Conservation Areas, which attempt to overcome these challenges. The driving force behind these approaches is that if properly designed and supported, these ancillary measures could complement the Chilean network of marine coastal biodiversity protected areas (Castilla 2000).

\section{Territorial user rights as possible ancillary conservation instruments}

Chile is among the 10 most important countries in terms of fishery landings (FAO 2010). Thus, biodiversity conservation has to be scaled up in the context of an extremely productive marine coastal ecosystem (Thiel et al. 2007). In the last 5 years the total aggregated industrial and artisanal wild species landings, have ranged, around 4.5 million tons/year (Castilla, 2010). Approximately 50\% of marine landings are based on artisanal fisheries operating in coastal zones (approximately $<10$ miles offshore; Castilla 2010). In Chile, to be classified as an "artisanal fisher", vessels must not exceed $18 \mathrm{~m}$ in length and have a maximum of up to 50 gross register tons (Fisheries and Aquaculture Law $\mathrm{N}^{\mathrm{o}} 18$ 892; Castilla 2010). Within coastal zones, the artisanal fleet supplies a significant fraction of high-valued finfish, small-pelagic fish, benthic invertebrate, and algal resources. For instance, between 2005 and 2012 around 32,000 artisanal fishers registered as divers extracted about 245,000 tons year $^{-1}$ of benthic resources (excluding algae), worth approximately 340 \$US million year $^{-1}$. (SERNAPESCA Servicio Nacional de Pesca 2005). Artisanal fin-fishers, during 2005-2012, extracted an average of 1.14 million tons year ${ }^{-1}$ of high value fin-fish and small-pelagic species, worth around 2465 US\$/ton (SERNAPESCA Servicio Nacional de Pesca 2005). The artisanal fleet also lands about 373000 tons year ${ }^{-1}$ of algae worth 250\$US million year ${ }^{-1}$ (SERNAPESCA 


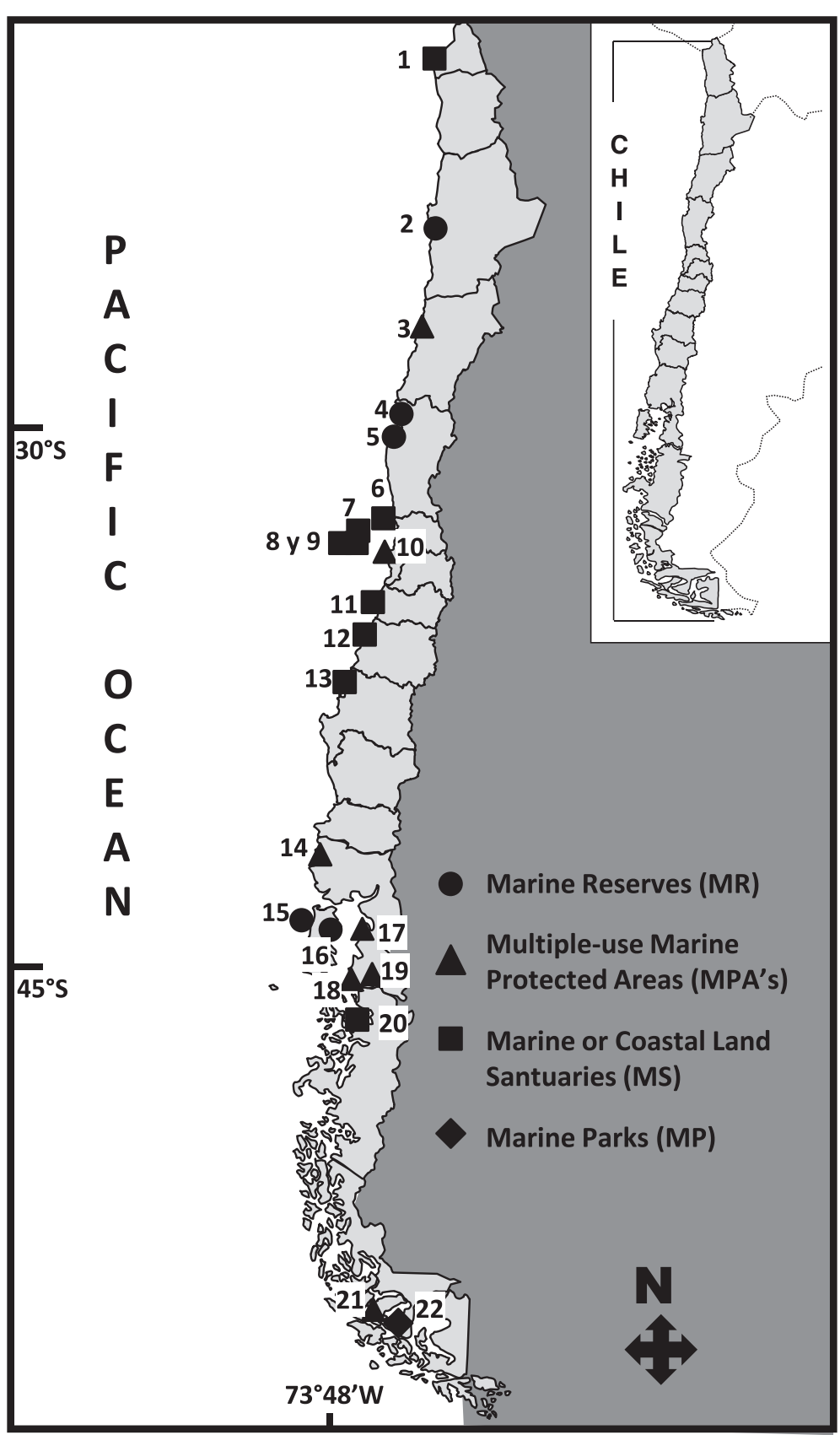

Figure 1 Map of Chile showing coastal protection areas which include marine and terrestrial ecosystems and their legal instruments. In the figure marine reserves (MR), Multiple use Marine Protected Areas (MPAs), Marine or coastal land Sanctuaries (MS) and Marine Parks (MP) are highlighted. Numbers in the figure represent: (1) MS Humedal de la Desembocadura del Río Lluta; (2) MR Bahía Moreno La Rinconada; (3) MPA's Isla Grande Atacama; (4) MR Isla de Chañaral; (5) MR Isla Choros-Damas; (6) MS Isla Cachagua; (7) MS Roca Oceánica; (8) MS Islote Pájaro-Niño; (9) MS Peñón de Peñablanca; (10) MPA's Las Cruces; (11) MS Bosque de Calabacillo de Navidad (Municipal); (12) MS Roca de Constitución; (13) MS Lobería de Cobquecura; (14) MPA's Lafken Mapu Lahual; (15) MR Pullinque; (16) MR Putemún; (17) MPA's Fiordo Comau-San Ignacio de Huinay; (18) MPA's Pitipalena-Añihue; (19) MPA's Tic-Toc; (20) MS Estero de Quitralco; (21) MPA's Francisco Coloane; (22) MP Francisco Coloane. 
Servicio Nacional de Pesca 2005). The legal framework (Fisheries and Aquaculture Law $\mathrm{N}^{\mathrm{o}}$ 18.892) that regulates fisheries in Chile provides a series of management policies such as marine zoning, regulating mobility of fleets, allocating exclusive territorial users rights for fisheries (TURFs), establishing management plans and establishing catch share systems for fully exploited species (Castilla 2010).

The TURFs policy implemented in Chile takes the form of Management and Exploitation Area for Benthic Resource policy (Castilla 1994). Through this policy the undersecretary of fisheries assigns exclusive access diving rights to fisher organizations (Castilla et al. 1998; Gelcich et al. 2010). The rational for establishing these user rights is based on common-property and co-management theories, which establish that securing access and sharing control over resources can create incentives for sustainable institutional arrangements among fishers, who will then manage and fish collectively and sustainably (Ostrom and Schlager 1996). In addition, it should contribute to more effective enforcement by increasing their likelihood of compliance (Jentoft et al. 1998). In order to be granted a TURF fisher organizations must actively engage in developing (with the help of biological consultants) official management plans. They are also responsible for surveillance and enforcement of anti-poaching measures (Castilla 2008). The first TURF was informally established in 1989 (Castilla et al. 1998). Currently in Chile there are 707 TURFs legally allocated to fisher organizations (Sernapesca 2010). Although there is heterogeneity in their performance, they account for more than $1,100 \mathrm{~km}^{2}$ of the nearshore seascape, with an average size of approximately $100 \mathrm{~h}$ and an average distance between them of 4-10 km (Gelcich et al. 2010). TURFs are created and assessed considering economically important benthic species such as the carnivorous muricid gastropod Concholepas concholepas (considered in $80 \%$ of TURFs), keyhole limpets, Fissurella spp. (70\%), and the red sea urchin Loxechinus albus (30\%) and more recently for algae species (Castilla et al. 1998; Castilla et al. 2007). Biological studies of TURFs policy have proclaimed substantial increases of abundances and sizes of managed species within well enforced TURFs in comparison with open-access areas (Castilla et al. 1998).

In Chile the discussions on the role of TURFs as ancillary conservation instruments have historically been absent of the debate on scaling up marine conservation (Gelcich et al. 2011). Recently, the biodiversity conservation implications of TURFs began to be assessed scientifically (Gelcich et al. 2008, 2012). Results of these studies showed that TURFs can sustain densities and biomasses comparable to that of a fully protected notake MPA for target species. TURFs also had significantly higher reef fish and macroinvertebrate species richness, biomass, and density compared with open-access areas (Figure 2). Furthermore, results suggest that the level of enforcement, aimed at preventing poaching in TURFs, is associated with biological diversity (Figure 2). Despite these benefits provided by TURFs for the subtidal communities, No-take MPA of around 20 hectares in size show higher density, biomass, and species richness of macroinvertebrates and reef fishes than TURFs, which indicate TURFs cannot replace no-take MPAs (Gelcich et al. 2012, Figure 2). In essence, biodiversity benefits from well managed TURFs are somewhere in between open access and No-take MPA levels.

The presence of TURFs, although probably providing fewer conservation outcomes than a no-take MPA, does allow marine conservation to scale-up in size. In continental Chile there is potential for conservation in 1,100 km2 of TURFs, with enforcement and 


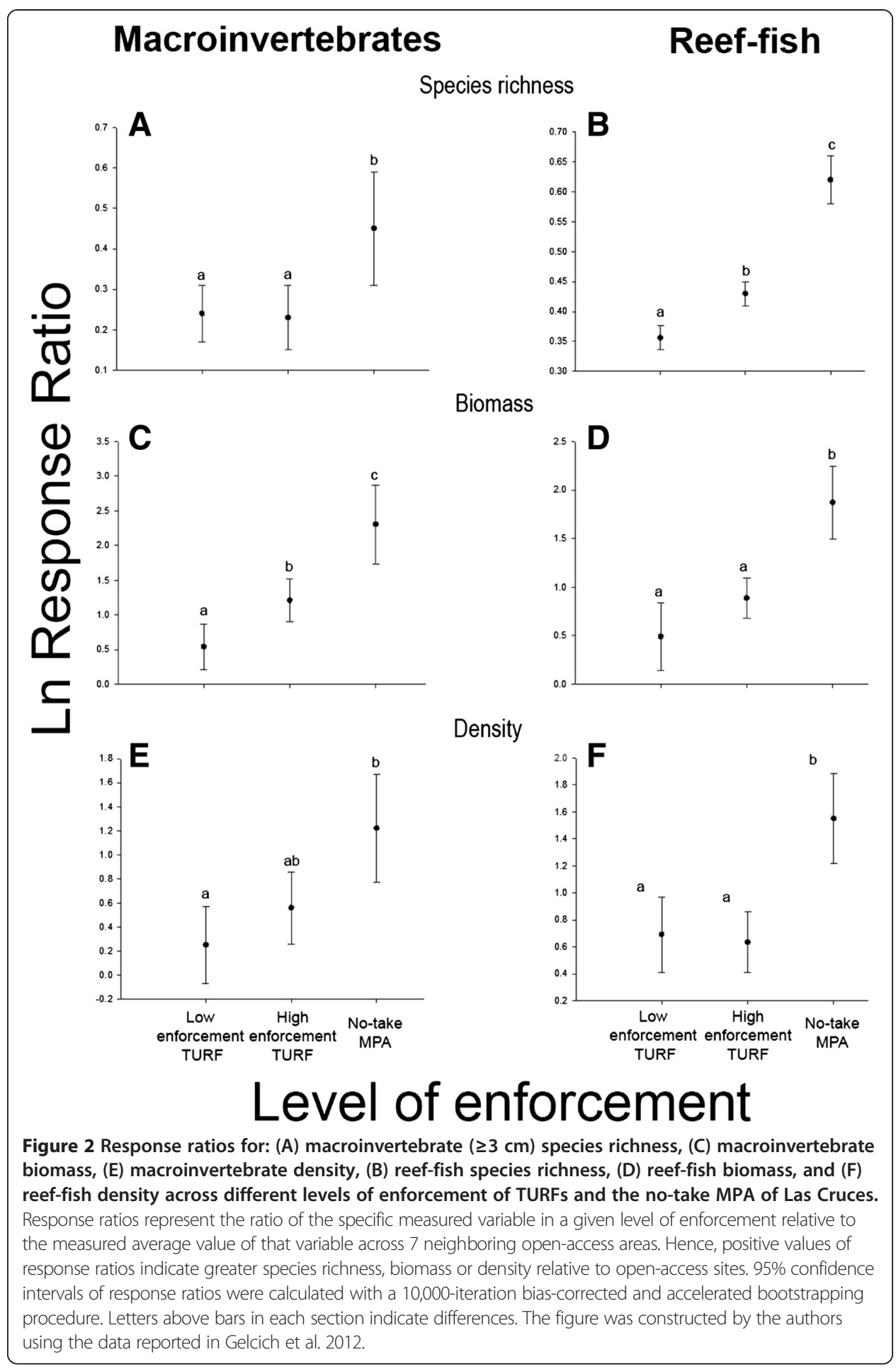

surveillance in hands of artisanal fishers. There is also empirical evidence that the participation of fishers in TURFs has increased their stewardship capacity (Gelcich et al. 2008). Thus, it becomes imperative to assess and recognize the value of these ancillary measures in terms of effective marine conservation and to establish financial mechanisms to optimize their contribution (Gelcich et al. 2011). 
An interesting model that is currently under consideration and analysis which could improve the potential of TURFs to scale up biodiversity conservation relates to the establishment of no-take zones within a portion of a TURF (Gelcich and Donlan, in press). Initial pilot case studies are being established to test this alternative, with promising preliminary results (Gelcich and Donlan, in press; www.advancedconservation. org). The aimed outcome of generating no-take MPAs within TURFs is a scalable program that can provide a supplementary revenue stream to fishers in exchange for management actions that produce enforced and verified biodiversity benefits, while also promoting sustainable fisheries (Gelcich and Donlan, in press).

Depending on how biodiversity incentive schemes are established, optimizing biodiversity within TURFs through establishing no-take zones within their boundaries can become a cost effective measure. TURFs hold the potential to enable at least two business model innovations that could improve fishers' livelihoods with biodiversity benefits. First, outcomes from conservation practices, such as the implementation of no-take areas within TURFs, could be commoditized and sold as credits in offset type markets (Gelcich et al. 2011, Donlan 2015). Because there are on-going marine and coastal impacts from the private and public sector throughout Chile, we anticipate opportunities for marine biodiversity offset programs. In fact, the Chilean government has recently modified important aspects of environmental impact assessment policy to allow offsetting. In addition, it is in the process of revising the offset framework within a new biodiversity and protected area policy. Second, biodiversity benefits from TURFs could be integrated and add value to products within emerging sustainable seafood markets (e.g., traceable seafood products with biodiversity benefits). Both these alternatives build upon basic conditions enabled by the TURFs, however to develop these concepts further requires the construction of learning platforms, collaborative demonstration-scale experimental trials where fishers, managers and scientists can co-construct the necessary knowledge.

Informing on innovative conservation approaches which are based on TURFs and their potential to scale up marine biodiversity conservation will require an understanding of biodiversity response, the development of financing strategies, which must be tailored to local realities, an understanding of the demand for biodiversity credits and fishers behavioral responses. New interdisciplinary approaches will be critical to solve these emerging research frontiers.

\section{Municipal conservation sanctuaries as possible ancillary conservation instruments}

Since the 1992 UN Conference on Environment and Development of Rio, international and national approaches to conservation have had to harmonize with social needs and the development agenda (Adams 2001). As a part of this process the concept of good governance of protected areas has evolved and is currently associated with fair methods, negotiation processes and the search for consensus among a plurality of actors and interested parties. This should result in building better bases for societal decision making (Borrini-Feyerabend et al. 2004). Concomitantly research and international fora have identified challenges related to promoting broad participation of interested parties in the management of protected areas and the fair and equitable distribution of the benefits derived from conservation (Adams 2001). A basic element of these 
transitions is the principle of subsidiarity which holds that a larger and greater body should not exercise functions which can be carried out efficiently by one smaller, but rather the former should support the latter and help to coordinate its activity with the activities of the whole community. As a way to promote the abovementioned principles in conservation, the IV World Congress of Nature emitted resolution 4.037 regarding municipal conservation areas. This resolution urges the director general of IUCN to "recognize the value of Municipal Conservation Areas for biodiversity conservation and their importance for increasing the effectiveness of protected area systems; and develop the capacity to promote and assist initiatives involving members in the creation and strengthening of Municipal Conservation Areas through technical and financial support" (UICN Unión Internacional para la Conservación de la Naturaleza 2009 44-46). While municipal conservation areas can become a burden for municipalities who have no access to support networks and financial resources, the resolution establishes municipal conservation areas can become a suitable instrument for attempting to reach the goals of biodiversity conservation by linking conservation efforts with local needs. They also have the potential to contribute to efforts to generate more polycentric types of management for protected area systems (Ostrom et al. 1961).

In Latin America municipal conservation areas are relatively new phenomena, with only a few experiences which focus primarily on terrestrial environments from which to draw lessons (GTZ cooperación técnica alemana 2010). In Chile there is great potential to develop municipal conservation areas; there are 345 municipalities out of which 101 are in coastal zones (Gelcich et al. 2009b). In addition, Chile already counts with a National Municipality legislation named the The Ley Orgánica de Municipalidades de Chile, which requires that every municipality in the country establish a four year planning and management instrument, including comprehensive regulations, addressing the sustainability, rational management and conservation of resources and the environment within the municipality territories and/or ecosystems (Gelcich et al. 2009b).

Unfortunately, despite municipalities' potential in scaling up marine conservation, so far there is no clear legal approach through which municipalities can obtain management rights and funding to conserve marine areas, or is there a formal recognition of the role they can play for scaling up marine biodiversity conservation. Thus there is an urgent need to develop and support learning platforms and strengthen management skills, to highlight the real potential of marine municipal conservation areas.

One example of municipal marine conservation in Chile has been developed in Navidad, Libertador Bernardo O’Higgins Region, Chile. In Navidad, the local municipality, fisher unions and university academics began the process of applying for a notake marine reserve in a united way in 2005. The initiative relies on collaboration of this diverse set of stakeholders that operate at different levels. The process of selecting sites and developing the base-line studies took approximately 4 years and was a collaborative process between fishers, academics and municipal officials. In addition, fisher union presidents, academics and the local council held meetings with all artisanal fishers with the objective of modifying and validating the results from site selection and base-lines (Oyanedel et al. 2015). Outreach of the final decisions towards the broader civil society was led by the municipality and fisher unions (Figure 3). In addition educational activities surrounding the sanctuary initiative have been a constant element (Figure 3). 


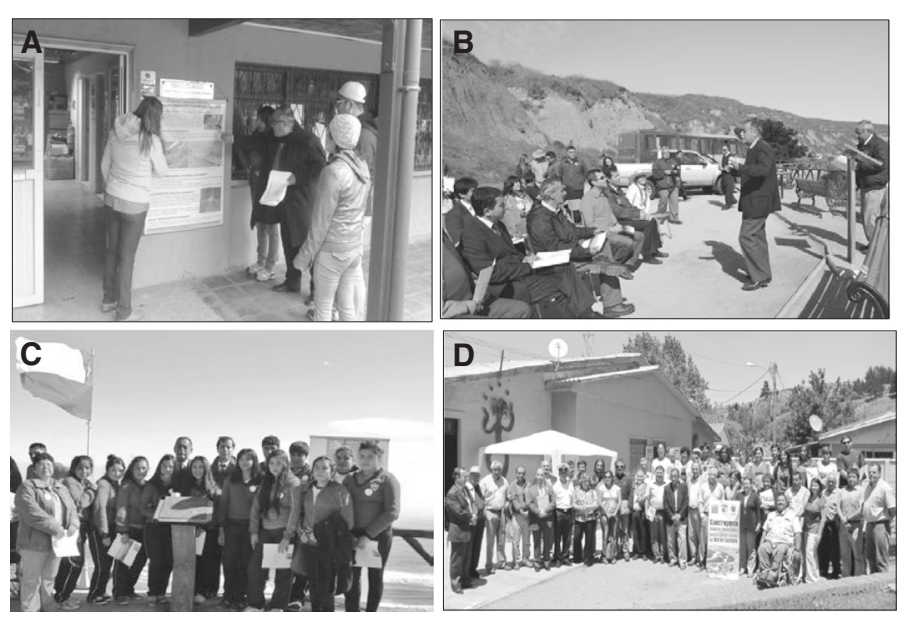

Figure 3 Photo panel showing A) Informative panels that explain to the community and tourist about the marine conservation initiative carried by local fishers, the municipality and scientist of the Universidad Catolica de Chile. B) Opening ceremony where the Marine Municipal Sanctuary area of Navidad was officially established. C) Educational field activity developed by the Municipality for local students to learn about marine conservation. D) Outset of the "Alliance of Coastal Municipalities for Sustainable Development", where eight costal municipalities committed to work together to re-vindicate their rights to manage and conserve marine coastal environments.

The municipality-fisher-university collaboration brought new ideas regarding ways to conserve marine biodiversity, but more importantly, it brought in networks of contacts that help members of the fisheries union to access non-local institutions and resources (Gelcich et al. 2010). An analysis of communication, support and information networks of the Navidad initiative show how these three aspects were enhanced through the process of application and design of the marine sanctuary (Oyanedel et al., 2015). The fact that expanding and linking networks of exchange helps facilitate integrated and inclusive coastal management is not new. Tomkins et al. (2002) in Trinidad and Tobago show how those networks spread across national and international boundaries in ways that would have been hard for locals to do on their own. An important factor in developing this successfully is the presence of "linking organizations" between local actors and other scales of organizations. Linking organizations provide opportunities by bringing in resources, knowledge and other incentives to engage in marine conservation networks (Folke et al. 2005).

The Navidad marine Sanctuary is currently the first marine municipal conservation area in Chile. It was formally approved in 2013, eight years after the initial idea emerged from the fishers, municipality officials and university scientists (Oyanedel et al. 2015). The emergence and consolidation of the sanctuary demanded several collective action tasks (Ostrom, 1990). These include communication, coordination of actions, mechanisms for solving conflicts and information sharing. The organizational structure and the development of trust and reciprocity between stakeholders which emerged during the 8 years were instrumental in confronting this challenge (Oyanedel et al. 2015). In essence, these bottom-up partnerships for marine conservation did not emerge automatically in response to potential benefits. There was a need to address transaction costs associated to participation, communication and engagement disparities at local scales (Oyanedel et al. 2015). 
The Navidad marine Sanctuary is not an isolated experience; there is an increasing interest for marine municipal conservation areas from mayors, local councilors and communities in Chile. For instance in Ancud, located in the Chiloe island, the local municipality with help from NGOs and the support of fisher communities established a binding municipal rule (Ordenanza Municipal in Spanish) to regulate access and visiting frequency to a penguin colony in its coastal zone. In addition, in other areas of Chile, artisanal fisher Unions have managed to summon several stakeholders to begin to locally work on zoning coastal areas, which can then be validated by Municipalities.

Experiences such as the ones above, in which coastal municipalities have engaged in marine biodiversity conservation, have triggered interest and support of other municipalities in Chile. As a product of this, on the 27th - 28th of January 2011 eight municipality mayors with their environmental specialists got together and formed the "Alianza de Municipios Costeros por el Desarollo Sostenible” (Aliance of Coastal Municipalities for Sustainable Development: Figure 3) an alliance which manifests its right to be recognized as managers of marine biodiversity and therefore a right to participate in designing marine public policy and coastal spatial planning (Gelcich et al. 2011). The alliance is open to new coastal municipalities in Chile wishing to collaborate. Ideally, this initiative could help inform legislation to acknowledge municipal marine protected areas as part of a future national system of protected areas and engage the international conservation community to support and finance the creation of capacities and social capital for their development.

\section{Discussion and conclusion}

Policy decisions regarding conservation and management of natural resources directly affect fishers and coastal inhabitants' ability to maintain their communities and livelihood. Traditionally, these policies have tended to be driven in a top-down manner and consider the biophysical aspects of management decisions first and the socioeconomic impacts secondly. Experience from Chile, presented in this paper, suggests that in order to effectively scale up marine conservation practices in order to achieve both international commitments and effective coastal governance it might be more effective to emphasize socioeconomic aspects and develop mechanisms that acknowledge participation of civil society early in the process.

Participation in MPA processes tends to promote desired changes by having community members empowered with a sense of ownership (Pollnac and Pomeroy, 2005). Research which has explored experiences from municipal conservation areas show that the collaborative work aimed at facilitating dialogue and solutions, which led to the establishment and implementation of the Navidad MPA, paved the way for a consolidation process (Oyanedel et al. 2015). However the widespread implementation of municipal conservation areas is challenging, common interests do not necessarily lead to successful implementation, funding constraints and the lack of capacities could jeopardize these initiatives. However, external agents can support these processes by facilitating dialogue and finding solutions (White and Runge, 1995).

Creating market (i.e., non-regulatory) incentives to establish enforced, no-take zones within TURFs presents an opportunity to integrate livelihood improvement and marine biodiversity protection (Gelcich and Donlan, in press). In principle, using this strategy 
as an ancillary conservation instrument could apply to any small-scale TURFs fishery across the globe. Yet, not all TURFs are created equally, and they have been created mainly as fisheries management tools. Thus, exactly how a program can incentivize human behavioral changes to produce biodiversity benefits and how those benefits can be financed will depend on local social-ecological conditions. Important conditions which must be considered include the existence of latent biodiversity benefits and fishers' capacity to enforce TURF areas. Local enforcement by fishers not only requires a system of local governance and financial incentives, but also cross-scale linkages with regional and national institutions that can develop and support effective enforcement (CudneyBueno and X. Basurto 2009; Gelcich et al. 2010).

In essence, it is important to highlight that the recognition of ancillary conservation measures for marine conservation must be coupled and integrated to existing centralized experiences to achieve success. The dichotomy between top-down and bottom-up processes must turn into a synergy between these processes (Carcamo and Gaymer, 2013). In Chile evidence shows there is a strong potential for bottom-up processes in marine conservation, but there is also a need for top-down steering and guidance (Gelcich et al. 2009a). Cross scale linkages between scales of governance are crucial for the provision of services, goods and infrastructure related to the protection and enhancement of marine biodiversity, the economic development of community enterprises, and the political representation of communities (Grilo 2011).

Marine conservation in Chile is undergoing an important transformation. The newly elected government of Michelle Bachelet which took office in March 2014 has highlighted the need to establish a "National Service of Protected Areas and Biodiversity" which will gather and concentrate the diverse conservation instruments in both land and sea, under an integrated environmental governance scheme. This represents a key opportunity to highlight the role that ancillary conservation instruments such as TURFs and Municipal conservation areas could have in scaling up and managing marine biodiversity. This overarching national framework for conservation must also begin to consider the development of innovative financing mechanisms such as voluntary biodiversity offset programs (McKenney and JM Kiesecker 2010; Donlan, 2015) and market based mechanisms to finance conservation (Lester et al. 2013). The ancillary efforts presented here have the potential to enhance the overall governance of coastal natural resources and improve livelihood security of the people involved. Developing these issues further will require a planned research agenda including multidisciplinary teams, who must inform political discussions to generate the learning process for effective conservation of coastal zones.

By synthesizing information on the key processes involved in the development of pilot ancillary conservation initiatives, our goal has been to establish a better understanding of the broader foundations for innovating on ways in which marine conservation outcomes can be scaled up while accounting for local governance and livelihood realities. Important paradigm shifts which must be considered in a marine conservation agenda for Chile and Latin America must consider an evolution from conservation run by central government to that run by multiple-partners, including local communities, the private sector and NGOs. An evolution from conservation paid for by taxpayers to that paid for from multiple sources to achieve self-sustaining (Gelcich et al. 2013). Furthermore, a major shift is needed, signaling that marine 
coastal conservation should not only benefit visitors and tourists, but also, local communities, which assume the opportunity costs of conservation. We advocate that acknowledging and developing the concept of ancillary conservation measures is one way of including these paradigm shifts in marine conservation policies, not only in Chile, but more broadly in Latin America.

Competing interests

The authors declare that they have no competing interests.

\section{Authors' contributions}

All authors contributed to the review, drafted, read and approved the final manuscript.

\section{Acknowledgements}

We thank Financiamiento Basal FB-0002, nucleo-milenio initiative RC130024 and NC-120086 from the Ministerio de Economia, Fondecyt 3150138, The David and Lucile Packard Foundation and The Pew Marine Conservation Fellowship Program.

\section{Author details}

'Centro de Conservación Marina, Departamento de Ecologia, Pontificia Universidad Católica de Chile, Alameda 340, Santiago 8331150, Chile. ${ }^{2}$ Center of Applied Ecology and Sustainability (CAPES), Facultad de Ciencias Biológicas, Pontificia Universidad Católica de Chile, Alameda 340, Santiago 8331150, Chile. ${ }^{3}$ llustre Municipalidad de Navidad, Comuna de Navidad, Chile. ${ }^{4}$ Advanced Conservation Strategies, Cordoba, Spain \& Department of Ecology and Evolutionary Biology, Cornell University, Ithaca, NY, USA.

Received: 11 June 2014 Accepted: 12 March 2015

Published online: 14 May 2015

\section{References}

Adams, WM. 2001. Green Development. Environment and Sustainability in the Third World. London: Routledge. Borrini-Feyerabend, G, A Kothari, G Oviedo. 2004. Indigenous and Local Communities and Protected Areas: Towards Equity and Enhanced Conservation. IUCN, Gland, Switzerland and Cambridge, UK. xviii + 111pp.

Carcamo, FP, and CF Gaymer. 2013. Interactions between spatially explicit conservation and management measures: Implications for the Governance of marine protected areas. Environmental Management 52: 1355-1368. 10.1007/ s00267-013-0167-9.

Castilla, JC. 1994. The Chilean small-scale benthic shellfisheries and the institutionalization of new management practices. Ecology International Bulletin 21: 47-63.

Castilla, JC. 1996. La futura red chilena de parques y reservas marinas y los conceptos de conservación, preservación y manejo en la legislación nacional. Revista Chilena de Historia Natural 69: 253-270.

Castilla, JC. 2000. Roles of experimental marine ecology in coastal management and conservation. Journal of Experimental Marine Biology and Ecology 250: 3-21.

Castilla, JC. 2008. El océano y la conservación en Chile: Los eternos olvidados. Estudios Públicos 112: 206-217.

Castilla, JC. 2010. Fisheries in Chile: small-pelagics, management, rights and sea zoning. Bulletin of Marine Science 86: 221-234.

Castilla, JC, S Gelcich, and O Defeo. 2007. Successes, lessons, and projections from experience in marine benthic invertebrate artisanal fisheries in Chile. Pages 25-42 in Fisheries management: progress toward sustainability, ed. T. McClanahan and J.C. Castilla, Oxford: Blackwell.

Castilla, JC, PH Manríquez, J Alvarado, A Rosson, C Pino, C Espóz, R Soto, and O Oliva Defeo. 1998. Artisanal Caletas: as units of production and co-managers of benthic invertebrates in Chile. Canadian Journal of Fisheries and Aquatic Sciences (Special Publication) 125: 407-413.

CBD. 2004. CBD Technical Series number 13. Montreal, Quebec: Canada. Secretariat of the Convention on Biological Diversity: technical advice on the establishment and management of a national system of marine and coastal protected areas.

CBD. 2013. CBD Quick guides to the Aichi Biodiversity Targets, Retrieved 25 August, 2013, from http://www.cbd.int/sp/targets/.

Cudney-Bueno, R., and X. Basurto. 2009. Lack of cross-scale linkages reduces robustness of community based fisheries management. Public Library of Science ONE 4: doi:10.1371/journal.pone.0006253.

Donlan, CJ (ed) 2015. Proactive Strategies for Protecting Species: Pre-listing Conservation and the Endangered Species Act. Berkeley, CA: University of California Press.

FAO. 2010. El estado mundial de La pesca y Acuicultura. Departamento de Pesca y Acuicultura de la FAO. Roma: Organización de las Naciones Unidas para la Agricultura y la Alimentación.

Fernández, M, and JC Castilla. 2005. Marine conservation in Chile: historical perspective, lessons, and challenges. Conservation Biology 19: 1752-1762.

Folke, C, T Hahn, P Olsson, and J Norberg. 2005. Adaptive governance of social-ecological systems. Annual Review of Environment and Resources 30: 441-473.

Gelcich, S, N Godoy, L Prado, and JC Castilla. 2008. Add-on conservation benefits of marine territorial user rights fishery policies in central Chile. Ecological Applications 18: 273-81.

Gelcich, S, N Godoy, and JC Castilla. 2009a. Artisanal fishers' perceptions regarding coastal co-management policies in Chile and their potentials to scale-up marine biodiversity conservation. Ocean and Coastal Management 52: 424-432

Gelcich, S, O Defeo, O Iribarne, G Carpio, R DuBois, S Horta, JP Isacch, N Godoy, PC Peñaloza, and JC Castilla. 2009b. Marine ecosystem-based management in the Southern Cone of South America: Stakeholder perceptions and lessons for implementation. Marine Policy 33: 801-806. 
Gelcich, S, TP Hughes, P Olsson, C Folke, O Defeo, M Fernández, S Foale, LH Gunderson, C Rodríguez-Sickerth, M Scheffer, RS Steneck, and JC Castilla. 2010. Navigating transformations in governance of Chilean marine coastal resources. Proceedings of the National Academy of Sciences 107: 16794-16799.

Gelcich, S, L Peralta, C Gonzalez, A Camano, M Fernandez, and JC Castilla. 2011. Scaling-up marine coastal biodiversity conservation in Chile: A call to support and develop ancillary measures and innovative financing approaches. In Successful and Failed Experiences in Biodiversity Conservation: Lessons and policy recommendations from the American continent, ed. E Figueroa, 199-220. Santiago: Editorial Universitaria.

Gelcich, S, M Fernandez, N Godoy, A Canepa, L Prado, and JC Castilla. 2012. Territorial user rights for fisheries as ancillary instruments for marine coastal conservation in Chile. Conservation Biology 26: 1005-1015.

Gelcich, S, F Amar, A Valdebenito, JC Castilla, M Fernandez, C Godoy, and D Biggs. 2013. Financing marine protected areas through visitor fees: Insights from tourists willingness to pay in Chile. AMBIO 42: 975-984.

Gelcich S and I Donlan. In press. Incentivizing biodiversity conservation in artisanal fishing communities through territorial user rights and business model innovation. Conservation Biology.

Gravestock, P, MR Callum, and A Bailey. 2008. The income requirements of marine protected areas. Ocean \& Coastal Management 51: 272-283.

Grilo, C. 2011. Institutional interplay in networks of marine protected areas with community-Based Management. Coastal Management 39: 440-458.

GTZ (cooperación técnica alemana). 2010. Áreas de conservación municipal: una oportunidad para la conservación de la biodiversidad y el desarrollo local. Reflexiones y experiencias desde América Latina. Brasilia, DF.

Jentoft, S, B McCay, and D Wilson. 1998. Social theory and fisheries comanagement. Marine Policy 22: 423-436.

Kelleher, G. 1999. Guidelines for marine protected areas. IUCN, Gland, Switzerland and Cambridge UK. Available from http://data.iucn.org/dbtw-wpd/edocs/PAG-003.pdf (accessed November 2009).

Lester, SE, and BS Halpern. 2008. Biological responses in marine no-take reserves versus partially protected areas. Marine Ecology Progress Series 367: 49-56.

Lester, SE, C Costello, A Rassweiler, SD Gaines, and R Deacon. 2013. Encourage sustainability by giving credit for marine protected areas in seafood certification. PLoS Biology 11(12): e1001730. 10.1371/journal.pbio.1001730.

McKenney, BA, and JM Kiesecker. 2010. Policy Development for Biodiversity Offsets: A Review of Offset Frameworks Environmental Management 45: 165-176.

Micheli, F, BS Halpern, W Botsford, and RR Warner. 2004. Trajectories and correlates of community change in no-take marine reserves. Ecological Applications 14: 1709-1723.

Ministerio de Medio Ambiente. 2014. Access at http://www.mma.gob.cl/1304/w3-channel.html.

Mora, C, S Andrefouet, MJ Costello, C Kranenburg, A Rollo, J Veron, KJ Gaston, and RA Myers. 2006. Coral reefs and the global network of marine protected areas. Science 312: 1750-1751.

Ostrom, V, CM Tiebout, and R Warren. 1961. The organization of government in metropolitan areas: a theoretical inquiry. American Political Science Review 55: 831-842.

Ostrom, E, and E Schlager. 1996. The formation of property rights. In Rights to nature: ecological, economic, cultural and political principals of institutions for the environment, ed. S Hanna, C Folke, and K Maler, 127-157. Washington: Island Press.

Ostrom, E. 1990. Governing the Commons: The Evolution of Institutions for Collective Action. New York, NY: Cambridge University Press.

Oyanedel, R, A Marín, JC Castilla, and S Gelcich. 2005. Emergence and consolidation of Marine Protected Areas: Insights from two contrasting bottom-up initiatives in central

Pollnac, RB, and RS Pomeroy. 2005. Factors influencing the sustainability of integrated coastal management projects in the Philippines and Indonesia. Ocean \& Coastal Management 48: 233-251.

Reid-Grant, K, and M Bhat. 2009. Financing marine protected areas in Jamaica: An exploratory study. Marine Policy 33: 128-136.

SERNAPESCA (Servicio Nacional de Pesca). 2005-2012. Anuarios estadísticos de pesca. Servicio Nacional de Pesca. Ministerio de Economía Fomento y Reconstrucción. Available from: http://www.sernapesca.cl

Sernapesca. 2010. Areas de Manejo en Chile.. http://www.sernapesca.cl/. Accessed 16 Mar 2015.

Thiel, M, EC Macaya, E Acuña, WE Arntz, H Bastias, K Brokordt, PA Camus, JC Castilla, LR Castro, M Cortés, CP Dumont, R Escribano, M Fernandez, JA Gajardo, CF Gaymer, I Gomez, AE González, HE González, PA Haye, JE Illanes, JL Iriarte, DA Lancellotti, G Luna-Jorquera, C Luxoro, PA Manriquez, V Marín, P Muñoz, SA Navarrete, E Perez, E Poulin, J Sellanes, HH Sepúlveda, W Stotz, F Tala, CA AThomas, JA Vasquez Vargas, and A Vega. 2007. The Humboldt Current System of Northern-Central Chile: Oceanographic Processes. Ecological Interactions and Socioeconomic Feedback. Oceanography and Marine Biology: An Annual Review 45(195-344): 45.

Tognelli, M, M Fernandez, and P Marquet. 2009. Assessing the performance of the existing and proposed network of marine protected areas to conserve marine biodiversity in Chile. Biological Conservation 142: 3147-3153.

Tomkins, E, WN Adger, and K Brown. 2002. Institutional networks for inclusive coastal zone management in Trinidad and Tobago. Environment and Planning 34: 1095-111.

Turpie, JK, LE Beckley, and SM Katua. 2000. Biogeography and the selection of priority areas for conservation of South African coastal fishes. Biological Conservation 92: 59-72.

UICN (Unión Internacional para la Conservación de la Naturaleza). 2009. Resoluciones y Recomendaciones. Disponible en <http://data.iucn.org/dbtw-wpd/edocs/WCC-4th-005-Es.pdf>1. Consultado el 26 de julio de 2010. Gland: uicn.

Waldron, A, AO Mooer, DC Miller, N Nibbelinka, D Redding, TS Kuhnc, JT Roberts, and JL Gittlemana. 2013. Targeting global conservation funding to limit immediate biodiversity declines. Proceedings of the National Academy of Sciences of the United States of America 110: 12144-12148.

Watson, JEM, N Dudley, DB Segan, and M Hockings. 2014. The performance and potential of protected areas. Nature 515: 67-73.

Wells, S, N Burgues, and A Ngusaru. 2007. Towards the 2012 marine protected area targets in eastern Africa. Ocean \& Coastal Management 50: 67-83.

White, TA, and CF Runge. 1995. The emergence and evolution of collective action: Lessons from watershed management in Haiti. World Development 23: 1683-1698. 